\title{
The art of interpreting God's action in the theology of three medieval mystic women
}

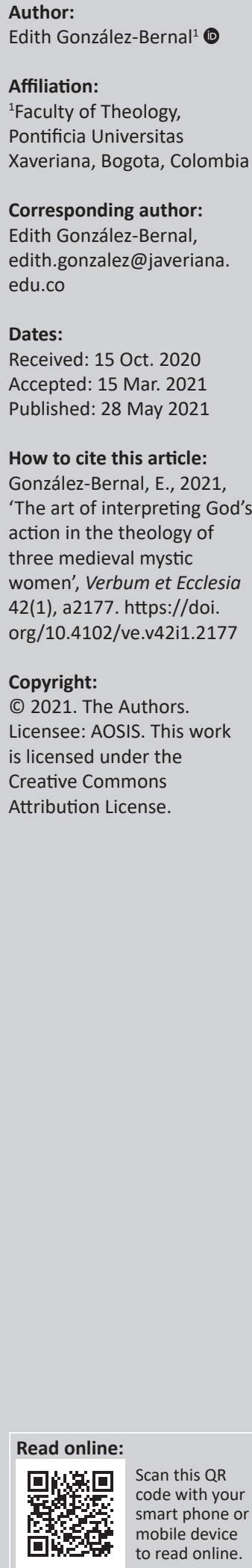

This study presents an approach to the theological minds of three Medieval mystical women: Matilde de Magdeburgo, Margarita Porete and Hadewijch de Amberes. Their theology is for the Church and theological matters, a source of wisdom, for they interpreted their experience of faith as imperative to make the gospel known. They lived in a time marked by significant developments in literature, artistic constructions and experiences of new spiritualities. They were part of an organisation of laywomen called the beguines who taught the art of interpreting God's action in the being. The medieval writing of courtly love, amorous dialogue and the mystics of nothingness resounded in them. The underlying question of our study was which theological categories did these beguine women rely on to interpret God's action in beings? As a point of departure, we performed the hermeneutic method to describe some of the theological categories that gave character to their thought, which aimed at enriching a theology that involved women's contributions, the methods with which they constructed the knowledge and the challenges they proposed. Their theology constituted a critical voice of the androcentric and patriarchal schemes that did not allow women to teach or talk about God.

Intradisciplinary and/or interdisciplinary implications: The interdisciplinary nature of the study is that the problem raised assumes a dialogue with other social science disciplines specifically. The way in which women construct a discourse on God's action in people implies taking into account anthropological, theological, psychological and literary elements. In their openness to God's action, human beings put into action their cognitive capacities and the knowledge derived from their cultural interaction in order to be able to speak about the experience of God in their lives. This study offers elements for fundamental theology and mystical theology.

Keywords: mystics; Beguine; self-denial; dialogue; forgiveness.

\section{Introduction}

This study intends to make visible the theological minds of three women distinguished as mystics for their teachings, organisation and lifestyle. They were noteworthy for their leadership and exceptional abilities to write about and systematise their experience of God's love and mercy. They were outstanding in the art of interpreting God's action through their adequate understanding of the human individual as a socio-culturally conditioned being, capable of striving for perfection.

Our goal is to describe the analytical categories of self-denial, annihilation of the soul to the will of God, the loving dialogue between God and the soul and reconciliation, pardon and gratuity. These mystics made God's action known through these practices with a consequential enrichment of today's theology.

We applied the hermeneutical method in our study which led us to the understanding and interpreting of the texts on medieval women as comprehensive and developmental structures. This revision implied a path of reading, interpreting and comprehending the word. In clear text, hermeneutics aids interpreters in making historical awareness of the foundation of comprehending any sort of message (Gadamer 1992:130). There were three instances in the steps we took to maintain the rigour of the method: (1) the search, select and classify the texts, which allowed the classification of information by degree of relevance and pertinence that a thematic revision has in perspective; (2) the reading of texts focusing on the theological categories that we set out to study and (3) the performance of analyses and hermeneutics by which the collected data were meticulously studied to understand the main arguments dealt with, the context they were drawn from and the conclusions that we reached. We, thus, proceeded taking into account that theology 
treated as hermeneutic knowledge would lead us to the understanding that interpretation is an art, practice and science, which in Geffrey's words 'is always a phenomenon of recasting a previous writing' (Geffre 1984:74).

The revision results of our study on the theology of medieval women help us understand from a historical point of view the struggle they took up in pursuit of equality and recognition for their art of interpreting God's action in a deeply patriarchal context. The beguines were laywomen who had become organised into groups to lead a free lifestyle with a deep evangelical commitment, service to the poorest and a life of prayer. They were women who challenged the androcentric models of the time. At the same time, their discourse of God, penned in their writings, annoyed a significant sector of the time's ecclesiastical authorities. Certain beguine tendencies, their fervent worship, mystical practice of abstinence and their poverty were enough to make them suspicious of heresy (Van Mierlo 1935:col 1344).

Studies made by Tanya feature a detailed profile of the beguines in Paris, their social commitment and their strikingly feminine spirituality (Tanya 2014). The beguines strongly impacted the life of the Church and society in general, according to Connally, as models of Christianity, and virtuosity, freedom, hospitality towards their sisters (Connally 2003).

Their lifestyle seemed scandalous to the Church to the point of being threatened with the suppression of their organisation. The Council of Vienne in 1312 alongside Pope Clemens V determined the prohibition, termination and exclusion of the beguine organisation.

They were free, intelligent, critical and proactive women with excellent inventive skills, leadership within society and an organisational vision that impressed many: "The main work of these women consisted of reforming the Church corroded by schisms, sclerosis, and simony, intellectual disenchantment and the restoration of new ways of the Christian' (Epiney-Burgard \& Zum Bum 2008: 16). Some were solvent women who decided to put their material possessions at the service of the poorest as a way to identify with the self-annihilation that Jesus proposes to lead a life of total abandonment for the poor.

It was explicit in their organisation's rules that they were not nuns. They were free to enter or leave whenever desired: 'They reserved the rights to private property and worked to support themselves. Since they did not take solemn vows, they were free to leave the association whenever they wished' (Wade Labarge 2003: 151). This lifestyle was unacceptable to the moment's ecclesiastical norms because the beguines did not submit to the clergy, nor did they depend on them. Furthermore, they did work for low wages that secured their economic independence and gave them more freedom to live a life of poverty as they perceived (Walter 2001):

The beguines specific understanding of apostolic poverty, for example, entailed that each member was required to earn her keep through low paying work. City governments, aware of the advantages of a local reservoir of cheap non-guild-regulated labor, endowed beguine communities with generous land grants to enlist their services. In some places, such as the city of Herentals, beguines at one point produced no less than 37.6 percent of all linen. (p. 346)

They were made to accept spiritual accompaniment the Church granted to women's religious communities, Cura Monalium, to validate their lifestyle and submit to control as to other sorts of control over consecrated women (Reindhart 2008:256). In the intellectual ambience, they were women who developed an art to create a theology advocating the knowledge of God parting from a deep experience of encounter with him (McGinn 1998:157). They were experts in the art of interpreting God's action using allegories based on the style of the great masters. Therefore, they recreated the Sacred Scriptures' interpretation, so that the imagination, symbols and comparisons play a creative piece between the identical and the diverse, the known and the unknown, repetition and comparison (Mafla Terán, Bernal \& Muñoz 2020:1-22).

\section{Who were these mystical women?}

They were women who developed an allegoric theology where scripture is reread and updated encouraging further new ways of interpretation. These were audacious women; they profess a critical stance before apparently non-objectable and irrefutable affirmations in theology and magisterium, mostly containing patriarchal discourses and excessive selfreference. Also, they questioned the classist and aristocratic thoughts about humans and, thus, opened a path (from a religious and biblical-theological conception) towards a conception of the person based on their integrity and integrality as well as other considerations in the ideological, political or economic order.

Matilde de Magdeburgo is the Holy Kiss of Love woman, the love that is union with God and fruition in him. She was a descendant from a rich and noble family and was highly educated (Dizzionario 1998:799). Her life is altered by the experience of an encounter with God, which she could generously describe and condense as her great and only work entitled fliebende Licht der Gottheit (The flowing light of the Godhead). It has been kept totally intact with the label of a beguine called Matilde (Poor 2004:73). There are units in the book that vary in length with narrations of mystical visions, letters, allegories and reflections (Ruh 1977:265-277). The original text was written in low German or central middle German dialect and translated into German and Latin. She makes known that her mystical experiences began at the age of 12 (Otero Villena 2016:1 XXI) and continued throughout her whole life.

Margarita Porete is the woman of lady-love, near-far (divine characters), and annihilated soul (the human individual), the annihilated woman. According to autobiographical data, she was born towards 1250 in the north of France. She became a 
beguine in 1290 and wrote her only book entitled 'Mirror of Simple Souls' in old French and later translated into various languages. As a result of this book, she was accused of heresy, persecuted, condemned and executed by the Holy Inquisition in Paris, on 1 June 1310. A crowd had assembled around the fire, wanting to witness the sentence; they were moved by the integrity, nobleness and spirit of the one to die (EpineyBurgard \& Zum Bum 2008:207). Studies made by Field amply describe her trial and the struggle to save her from her death at the stake (Field 2012).

She conceived the relation as being directly between the soul and God, void of intermediaries, intercessions and negotiations (Borriello et al. 1998:1468). She was a free woman, struggling to the end on account of her convictions (Kiner 2017:77). She gave up her life in liberty although she could have retracted. She silently refused to do so, because of her loyalty to her thoughts and experience of God. She said accordingly: 'The enemies who so wished to challenge a soul, even not finding it, will not get a response. The free Soul that is with God needs nothing' (Porete 2005:134).

She builds her book on a dialogue between the soul and God. She introduces God as Love and in later stages as reason. Reason represents the place where the sciences are founded and Soul represents the place of the understanding of Love, that is, the place of the encounter with God. The book's structure suggests that the topics were sought and carefully treated (De Gier 2014:127-150), thereby demonstrating a theology of experiential character that stirred concern for its knowledge and the demand for a path of annihilation or detachment, so that God may fill the individual. The philosophical and theological categories she develops indicate that she maintained social dealings with teachers or scholars of the time (Dubois 2017:174-192).

Hadewijch De Amberes (1986) is known as the woman of the outpouring and wound of love. God-Love is the recurring term in her written art. Some authors place her birth date towards the end of the 12th century, born from an Antwerp family. She became a beguine and was known for her leadership within the movement. She wrote in middle Dutch: 'God, Love, and Lover' and 'The Letters and Flowers of Flanders' (De Amberes 1986). She was distinguished for her visions, letters and poems. Her letters are a way to explain her courtly God-Love experience to her peers (EpineyBurgard \& Zum Bum 2008:131).

Furthermore, her lyrics are the expression of a woman considered a troubadour and poet of God. Her writings speak of the union with God, the cross of Jesus Christ, the tenderness of God's love and the suffering caused by the absence of God. The Spanish translator of her writings admits that what first comes to light in her works is 'an awesome culture, for not only does she master Dutch but also without a doubt she knew Latin and very likely French as well' (Cirlot \& Gari 2008:78).

\section{The path to the annihilation or termination of the soul to the will of God}

These women speak of an annihilated, terminated, purified and illuminated soul made to see God's splendour. An annihilated soul takes on the road of ascension and can come to exclaim like Saint Paul: 'It is not I that lives; it is Christ that lives in $\mathrm{me}^{\prime}$ (Gl 2, 20). For Mechthild of Madgeburg, annihilated soul has a 'thirst for God and is devoid of worldly glory, does not feel affected by the reverence of men, embraces solitude, seeks rest, and remains in the last seat out of humility and love' (De Magdeburgo 2004:235). For Margarita Porete, the annihilated soul is one that has become mindful that the path to follow implies conversion and renunciation. That is, each day the human person must seek themselves less, so that God becomes more in them. With the act of renunciation, they insert themselves within the divine sphere. They place themselves in front of the mirror that reveals the self laden with egocentrism and fantasies. "The Soul does not seek sacred science amid the teachers of this century, but rather by rejecting the world and the self' (Porete 2005:54). The following of Jesus is founded only on the liberty and openness towards a new and generous love that touches human existence and remains there.

For Hadewijch of Antwerp, the annihilated soul strips itself. When standing before a mirror, it can see all God's images that are not a true likeness; all its ambitions and desires for power are nothing else but personal constructs that have hindered being true to self (Gonzalez-Bernal 2017:272). An annihilated detached soul is one where God may dwell and, thus, make himself an icon of divinity. The loving action of God invites the soul to self-denial and total abandonment.

In the abandonment of naked love, nothing created can exist, for Love divests those completely who resort to simplicity. Free of all modes, estranged from all images, that is the kind of life led by the poor in spirit. (De Amberes 1999:142)

Self-denial is an optional road where a detached, sober and unburdened life is always accepted, which is meaningful if walked with God. Through self-denial, one finds that he is there to support and show them the way.

\section{A path of dialogue of courtly love between God and the soul}

These mystics know that since the times of the Old Testament, God desires to converse with the human person and establishes a two-way dialogue with them. The free and loving God that the Israelites discover in their course of history becomes a paradigm, revealing that God connects to people based on a specific contractual dynamic: the alliance. Such dynamics is the scaffold that allows the people of God to accede to the friendship he offers (Alviar 2004:754). God reveals himself in the New Testament with a face and body in the persona of Jesus. 
For the Magdeburgo woman, the framework of understanding is God's self-communication which has taken place in Jesus of Nazareth, the human being in whom he believes and hopes. 'He appears to the disciples when the doors were closed when he frequently communicated divine dogmas through the external senses' (De Magdeburgo 2004:82).

Marguerite Porete (2005) presents a Creator God who makes Godself known to the creature by being God in the creature, believing in human goodness, emphasizing its capacity to establish a relationship with God:

This Soul has such great faith in God that there is no fear in being impoverished while their friend is rich. For their faith proves that the way they expect to encounter God is just so. The only way to keep up conversation and dialogue with Him is through the redemption or annihilation of the Soul, total abandonment in God, absolute trust in Him. (p. 61)

'For whomsoever strips their Soul of honors, wealth and friends, heart, body, and life will not have stripped them of anything shall God remain' (Porete 2005:62). The power of her theology is in the faith that is tested to the measure that all goods, acknowledgements and personal exaltations are passing events and can vanish at any given moment. In contrast, faith shall always be the light to see God, illuminate the most challenging moments of human life and become a lamp that dispels the darkness. As Pope Francis well describes it: 'Faith is borne from the living God that beckons and reveals to us his love, a preceding love we may rest and construct a life upon' (Francisco 2013).

Hadewijch's love style, a kind love, describes the profound needs to communicate with God to convey what is happening in the soul when in solitude and when the beloved is not in sight. 'He allows one to wander outside, always kept from delight, in love. He keeps one in the darkness, deprived of all the joys that should proceed on one's behalf' (De Amberes 1999:33). At this point, a theology is sketched, borne from the Lover's entrails and felt in the fervour of Love. According to life's law, not surrendering but restoring dialogue with their beloved seeks to communicate intensely. It is the desire to want God and be able to unite with him. 'To live authentically in accordance to the demands of love means to cling exclusively to the will of Love itself for its fulfillment' (De Amberes 1999:57).

\section{Road to reconciliation, forgiveness and gratuity}

For Matilde of Magdeburgo, gratuity arises from the experience of the closeness of reconciliation and God's forgiveness. She exposes a moved and compassionate God who suffers because of the consequences of human actions that cause destruction and pain in the face of reality. God offers himself as salvation, which is his nature and proof that his Kingdom is here. The teacher builds a narration derived from the Old Testament in which Abraham holds a conversation with God, interceding and supplicating for human life (Gn 18:20-31). She places this dialogue in the mouth of Jesus who begs the Father for sinners and proves that there is never a refusal towards them: 'God responds: My heart is incapable of rejecting a sinner. I follow them wherever possible and keep them in the deepest place to be unrecognized' (De Magdeburgo 2004:86).

Gratuity, according to Margarita Porete, is the effect of the individual's experience of salvation and God's goodness. The human being who has experienced the goodness of God interprets it in the light of the Word as the supreme good that must reign in the human life. One comes to know God's goodness through human evilness. In this sense, the teacher gives thanks for her human frailness before evil, because it is there that she discovers the privilege of possessing kindness.

God has given me and has overflowed all His goodness upon me. His goodness is made known to mankind through my evil. I am the eternal praise of God and the human creature's salvation. For the salvation of all creatures is nothing short of the knowledge of the goodness of God. (Porete 2005:162)

For Hadewijch, there is gratuity in reconciliation. It is the experience that invites vigilance in not allowing sin where divinity must be:

$[N]$ either heart nor mind could guess in what way a Lover looks at His Beloved, when Love is replenishing love. Do not squander one instant and run wounded through the density to contemplate true Love. (De Amberes 1999:221)

The mystic of Amberes conceives reconciliation and forgiveness as the effects of God's kindness working within the being. Reconciliation is the liberation from misfortune when there has been a negative answer to God. It is also the admittance of a kind God who allows the being to feel pardon if in union with him:

Your goodness pardons my ignorance, my senseless desires; this unlimited mercy you gave me for humankind. Yet I did not know your perfect justice [...] When you took me within you and let me know who you truly are, then I learned to love and be completely equal to you. (De Amberes 1999:168)

\section{Conclusion}

The novelty of these women's theology comes into view in the art of interpreting God's presence in the human being. The work that it demands is inner knowledge in offering a word of inspiration and questioning people's lives. They resorted to hermeneutics built on the question of the being's experience of God in their daily living and their consequential response. The writings of these teachers reveal an understanding of the experience of God containing profound meaning. Only then is the world no longer absurd, and a call to the being's fulfilment arises. They uniquely interpreted God's action as loving the body and considering human passions. It is his living presence working within the human being, intellect, entrails and heart. Their theology reveals an art of interpretation that leads to the confrontation of life before the great mystery, encouraging the believer to continually inquire about its meaning, the practice of freedom, values, desires and decisions. These are questions that allow the entry into a particular and fertile domain that 
perceives the presence that dwells inside the individual. They had to interpret the scriptures and tradition to convey that God, whom all had always spoken about, established a two-way communication with human beings and impelled a reconciling, liberating and redeeming action. They understood that following Jesus is through self-denial or Kenosis, which implies embracing one's humanity and vulnerability. Metanoia is the change of mindset and obedience to God's word. The justice practiced amongst the people of the Kingdom of God demands living together in solidarity. It is compassion that challenges the imagination to unveil the feelings of a lonely brother or sister in need. It is an ongoing conversation between God and man in which man recognises him as a friend who actually speaks to him and offers friendship.

\section{Acknowledgements Competing interests}

The author declares that she has no financial or personal relationships that may have inappropriately influenced her in writing this article.

\section{Author's contributions}

EGB is the sole author of this research article.

\section{Ethical considerations}

This article followed all ethical standards for research without direct contact with human or animal subjects.

\section{Funding information}

This research received no specific grant from any funding agency in the public, commercial or not-for-profit sectors.

\section{Data availability}

Data sharing is not applicable to this article as no new data were created or analysed in this study.

\section{Disclaimer}

The views and opinions expressed in this study are those of the author and do not necessarily reflect the official policy or position of any affiliated agency of the author.

\section{References}

Alviar, J.J., 2004, 'Hacia una teología personalista del Reino de Dios', Scripta theologica 36(3), 753-793.

Borriello, L., Caruana, E., Del Genio, M.R. \& Suffi, N., 1998, Diccionario de Mística [xxx], San Pablo, Madrid.

Cirlot, V. \& Gari, B., 2008, La mirada interior: Escritoras místicas y visionarias en la Edad Media, Ediciones Siruela, Madrid.

Connally, M., 2003, Les 'bonnes femmes' de Paris: des communautés religieuses dans une société urbaine du bas Moyen âge [xxx], Université Lumière, Lyon.

De Amberes, H., 1986, Dios, amor y amante. Las cartas. Traducidas del antiguo medioneerlandés por Pablo María Bernardo [God, Love and Lover. Hadewijch of Antwerp. The Letters], Ediciones Paulinas, Madrid.

De Amberes, H., 1999, Lenguaje del deseo Edición y traducción de María Tabuyo, Trotta, Madrid.

De Gier, I., 2014, 'Text as Authority: Marguerite Porete's Mirouer des simples ames', in V. Fraeters \& I. De Gier (eds.), En Mulieres religiosae. Shaping Female Spiritual Authority in the Medieval and Early Modern Periods, pp. 127-150, Brepols, Turnhout.

De Magdeburgo, M., 2004, La luz divina ilumina los corazones. Testimonio de una mística del siglo XIII. Introducción, traducción y notas de Daniel Gutiérrez, Monte Carmelo, Burgos.

Dubois, D., 2017, 'Natural and supernatural virtues in the thirteenth century: The case of Marguerite Porete's Mirror of Simple Souls', Journal of Medieval History 43(2), 174-192. https://doi.org/10.1080/03044181.2016.1261258

Epiney-Burgard, G. \& Zum Bum, E., 2008, Mujeres trovadoras de Dios. Una tradición silenciada en la Europa medieval, Ediciones Siruela, Madrid.

Field, S., 2012, The Beguine, the Angel and the inquisitor: The trials of Marguerite Porete and Guiard of Cressonessart, University of Notre Dame Press, Notre Dame.

Francisco, P., 2013, 'Exhortación Evangelii Gaudium', numerales 19 al 45, viewed 14 October 2020, from http://www.vatican.va/content/francesco/es/apost exhortations/documents/papa-francesco esortazione-ap_20131124_evangeliigaudium.html.

Gadamer, H.-G., 1992, Verdad y método, vol. I, Sígueme, Salamanca.

Geffré, C., 1984, El cristianismo ante el riesgo de la interpretación [xxx], Ensayos de hermenéutica teológica, Cristiandad, Madrid.

González-Bernal, E., 2017, Místicas medievales. El rostro femenino de la teología [xxx], Pontificia Universidad Javeriana, Bogotá.

Kiner, A., 2017, La nuit des behuines, Editions Liana Levi, Paris.

Mafla Terán, N., Bernal, E.G. \& Muñoz, J.S.T., 2020, 'Trazos pedagógicos del Maestro Eckhart en la conducción del ser humano hacia la unión en Dios [Pedagogical strokes of Master Eckhart in Leading of the Human Being towards Union in God]', Theologica Xaveriana 2020, 1-22. https://doi.org/10.11144/javeriana.tx70.tpmec

McGinn, B., 1998, The flowering of mysticism. Men and women in the new mysticism 1200-1350, Crossroad, New York, NY.

Mierlo, J. Van., 1935, 'Béguins, béguines, béguinages', In M. Viller (Dir.) Dictionnaire de Spiritualité, Fascicule V. col. 1344, Gabriel Beachesne et ses fils éditeurs, París.

Otero Villena, A., 2016, Matilde de Magdeburgo. La luz que fluye de la divinidad, vol. 1 XXI, Herder, Barcelona.

Poor, S., 2004, Mechthild of Magdeburg and Her Book. Gender and the Making of Textual Authority, University of Pennsylvania Press, Philadlephia, PA.

Porete, M., 2005, El espejo de las almas simples, Edición y traducción de Blanca Gari, Siruela, Madrid.

Reindhart, E., 2008, Por las rutas medievales del saber, Eunsa, España.

Ruh, K., 1977, 'Begine mystik. Hadewijch, Mechthild von Magdeburg, Marguerite Porete [Beguine mysticism. Hadewijch, Mechthild von Magdeburg, Marguerite Porete]', Zeitschrift für deutsches Altertum und deutsche Literatur 106(3), 265-277.

Tanya, S.M., 2014, The beguines of medieval Paris, Penn Press University of Pensylvania, Philadelphia, PA.

Wade Labarge, M., 2003, La mujer en la Edad Media, Nerea, Barcelona.

Walter, S., 2001, Cities of ladies: Beguine communities in the medieval low countries 1200-1555 [xxx], University of Pennsylvania, Philadelphia, PA. 